\title{
Effect of metal catalyzed oxidation in recombinant viral protein assemblies
}

\author{
Ricardo M Castro-Acosta, William A Rodríguez-Limas, Brenda Valderrama, Octavio T Ramírez \\ and Laura A Palomares*
}

\begin{abstract}
Background: Protein assemblies, such as virus-like particles, have increasing importance as vaccines, delivery vehicles and nanomaterials. However, their use requires stable assemblies. An important cause of loss of stability in proteins is oxidation, which can occur during their production, purification and storage. Despite its importance, very few studies have investigated the effect of oxidation in protein assemblies and their structural units. In this work, we investigated the role of in vitro oxidation in the assembly and stability of rotavirus VP6, a polymorphic protein.

Results: The susceptibility to oxidation of VP6 assembled into nanotubes (VP6 $6_{N T}$ ) and unassembled VP6 (VP6u) was determined and compared to bovine serum albumin (BSA) as control. VP6 was more resistant to oxidation than BSA, as determined by measuring protein degradation and carbonyl content. It was found that assembly protected VP6 from in vitro metal-catalyzed oxidation. Oxidation provoked protein aggregation and VP6 ${ }_{\mathrm{NT}}$ fragmentation, as evidenced by dynamic light scattering and transmission electron microscopy. Oxidative damage of VP6 correlated with a decrease of its center of fluorescence spectral mass. The in vitro assembly efficiency of VPGu into VP6 ${ }_{N T}$ decreased as the oxidant concentration increased.

Conclusions: Oxidation caused carbonylation, quenching, and destruction of aromatic amino acids and aggregation of VP6 in its assembled and unassembled forms. Such modifications affected protein functionality, including its ability to assemble. That assembly protected VP6 from oxidation shows that exposure of susceptible amino acids to the solvent increases their damage, and therefore the protein surface area that is exposed to the solvent is determinant of its susceptibility to oxidation. The inability of oxidized VP6 to assemble into nanotubes highlights the importance of avoiding this modification during the production of proteins that self-assemble. This is the first time that the role of oxidation in protein assembly is studied, evidencing that oxidation should be minimized during the production process if VP6 nanotubes are required.
\end{abstract}

Keywords: Protein oxidation, Carbonylation, Virus-like particles, Viral protein assemblies, Assembly efficiency

\section{Background}

Protein assemblies have gained increasing importance in the biomedical field, as they are used as vaccines, delivery vehicles and nanomaterials [1-4]. Viral proteins have a primary role in the field, as many of them are capable of self-assemble to form macromolecular structures with unique properties, such as virus-like particles (VLP) and other assemblies. The production of such complex structures can be challenging, as it is not sufficient to produce a pure protein, but the desired assemblies should be

\footnotetext{
* Correspondence: laura@ibt.unam.mx

Departamento de Medicina Molecular y Bioprocesos, Instituto de Biotecnología, Universidad Nacional Autónoma de México, A.P. 510-3, C.P. 62210, Cuernavaca, Morelos, Mexico
}

obtained in a reproducible and consistent manner [1,4]. Stability is a key property of assemblies that are to be used for pharmaceutical, biomedical or nanotechnological applications. However, proteins suffer modifications that can result in loss of stability and function. These modifications may be due to micro-environmental and environmental conditions and can occur during production, purification, formulation, storage and handling, causing irreversible changes in their quality and stability, such as deamidation, aggregation, mismatched S-S bonds and oxidation [5-7]. From these, oxidation is one of the most important, and therefore, most studied [8-10]. Oxidation has critical consequences for protein structure and function, disturbing intrinsic characteristics. In vivo protein oxidation 
has been related to several diseases, such as Alzheimer's, cancer, atherosclerosis and other chronic disorders $[10,11]$.

Protein oxidation has been extensively investigated by in vitro studies. Several groups have worked with proteins like bovine serum albumin (BSA), IgG, lysozyme, and human $\alpha 1$-antitrypsin, among others [12-16]. Oxidation reactions with 2,2'-azobis(2-amidinopropane) dihydrochloride (AAPH), $\mathrm{H}_{2} \mathrm{O}_{2},{ }^{\bullet} \mathrm{OH}$ or $\mathrm{O}_{2}{ }^{\bullet-}$ result in aggregation, structural damage, changes in physicochemical properties, cleavage, and changes in protein hydrophobicity and conformation [12-16]. Oxidative damage in proteins disturbs their three-dimensional structure due to accumulation of amino acid carbonylation, backbone fragmentation, cross-linking, unfolding, increase in hydrophobicity, and conformational modifications $[8-10,17,18]$. Only few reports have been published for viral protein macrostructure assemblies such as virus, virus-like particles, and other highly ordered assemblies. The effect of oxidation on viruses (adenovirus, bacteriophage MS2, cowpea mosaic virus, influenza virus and norovirus) has been studied in efforts to inactivate them [19-23]. Various sources of reactive oxygen species (ROS) have been tested, such as the Fenton reaction, $\mathrm{UV}_{254},{ }^{1} \mathrm{O}_{2}$, chlorine dioxide and free chlorine. ROS reacted with different sites on viral capsids, resulting in carbonyl formation, aggregation and conformational changes, as well as modifying the capsid cell binding capacity and diminishing virus infectivity [19-23]. However, to our knowledge, only a single report of the effect of oxidation on VLP exists. Tleugabulova et al. [24] studied the effect of oxidation on VLP of the hepatitis B surface antigen ( $\mathrm{HBsAg}$ ) oxidized with ammonium peroxodisulphate. Oxidation provoked VLP aggregation and cross-linking of $\mathrm{S}$ protein chains, leading to a complete loss of antigenicity. Such studies highlight the importance of further investigating the effect of aggregation on protein assemblies.

The structure of protein assemblies can result in an increased susceptibility to oxidation, as protein monomers are in close contact, which can result in chain reactions that could magnify the effect of ROS. Also, oxidation can damage protein assemblies, impede the assembly of monomers, or cause other alterations of the multimer. In this work, we investigated the effect of oxidation in a multimeric polymorphic protein, rotavirus VP6. Recombinant VP6 forms highly stable trimers that can self-assemble into different types of structures depending on $\mathrm{pH}$ and ionic strength $[25,26]$. VP6 assembled into trimers, nanotubes $\left(\mathrm{VP} 6_{\mathrm{NT}}\right)$ or icosahedra can be obtained $[25,26]$. VP6 nanotubes have proven to be useful as a recombinant vaccine against rotavirus [2,27], as adjuvants in other recombinant vaccines [27], and as scaffolds for the production of nanomaterials $[3,28]$. VP6 constitutes an ideal model for studying the effect of oxidation on protein assemblies, as its assembly is required for its application. In this work, metal-catalyzed oxidation (MCO) was exerted upon VP6 nanotubes and unassembled VP6, in order to investigate its effect on protein degradation, carbonylation, assembly capacity, and aggregation. In this article, the susceptibility of oxidation of assembled and unassembled protein forms were compared, and the effect of oxidation on viral protein assembly is reported for the first time.

\section{Results}

\section{VP6 nanotube characterization}

A typical VP6 nanotube preparation was characterized. The purity of VP6 was confirmed in reducing denaturing SDS-PAGE gels, which showed a single band with the molecular weight reported for VP6 (Figure 1A). Size exclusion chromatography (SEC) analysis showed two populations (Figure 1B), one that migrated at the column exclusion limit (peak 1), which corresponded to VP6 nanotubes $\left(\mathrm{VP} 6_{\mathrm{NT}}\right)$, and a second one with smaller size identified as $\mathrm{VP}_{\mathrm{U}}$ (peak 2), containing unassembled VP6 monomers and trimers. The population containing VP6 $6_{\text {NT }}$ constituted $95 \%$ of the total protein, which is a typical value obtained with this purification process $[3,29]$. The presence of $\mathrm{VP}_{\mathrm{NT}}$ structures was confirmed by TEM (Figure 1C). Intrinsic fluorescence spectra of aromatic amino acids were acquired for $\mathrm{VP} 6_{\mathrm{NT}}$ and $\mathrm{VP6}_{\mathrm{U}}$ at 280 (Trp and Tyr, Figure 1D) and $295 \mathrm{~nm}(\operatorname{Trp})$. $\mathrm{VP6}_{\mathrm{U}}$ had a fluorescence quantum yield 2 and 2.5 times higher than $\mathrm{VP} 6_{\mathrm{NT}}$, at 280 and $295 \mathrm{~nm}$, respectively.

\section{VP6 assembled into nanotubes is more resistant to} degradation by oxidation than unassembled VP6 and BSA Protein oxidation can result in degradation by fragmentation of the backbone, which can be evidenced by the disappearance of a stainable band in SDS-PAGE gels $[15,17]$. Degradation analysis was used to evaluate the susceptibility of nanotubes and disassembled VP6 to $\mathrm{H}_{2} \mathrm{O}_{2}$. For comparison, bovine serum albumin (BSA), a widely studied protein, was also subjected to oxidation. Gels were scanned and the intensity and area of each band were quantified by densitometry. Results are shown in Figure 2. Exposure to up to $10,000 \mu \mathrm{M} \mathrm{H}_{2} \mathrm{O}_{2}$ did not cause band disappearance in gels of treated BSA, VP6 $6_{\mathrm{NT}}$ or $\mathrm{VP}_{\mathrm{U}}$, even after $6 \mathrm{~h}$ of incubation with the oxidant (Figure 2A). As VP6 was not degraded by exposition to $\mathrm{H}_{2} \mathrm{O}_{2}$, all following experiments were performed only with MCO. In contrast, when exposed to $\mathrm{H}_{2} \mathrm{O}_{2}$ in $\mathrm{MCO}$, the VP6 and BSA bands disappeared although with different behavior (Figures $2 \mathrm{~B}$ and $\mathrm{C}$ ). While VP6, in either of its forms, resisted $\mathrm{MCO}$ up to $5 \mathrm{mM}$ of $\mathrm{H}_{2} \mathrm{O}_{2}$ for $1 \mathrm{~h}$, the BSA band decreased at $\mathrm{H}_{2} \mathrm{O}_{2}$ concentrations above $0.25 \mathrm{mM}$. Exposition to $\mathrm{H}_{2} \mathrm{O}_{2}$ in $\mathrm{MCO}$ for $6 \mathrm{~h}$ caused degradation of BSA at all concentrations tested, evidencing that it is less resistant to degradation than VP6. These 


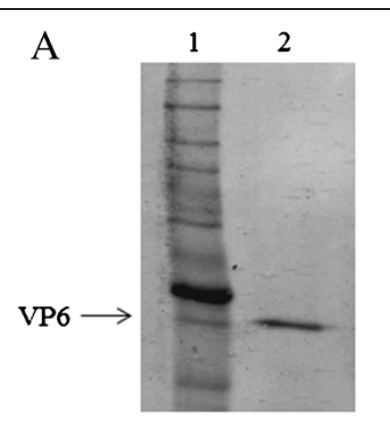

$\mathrm{C}$

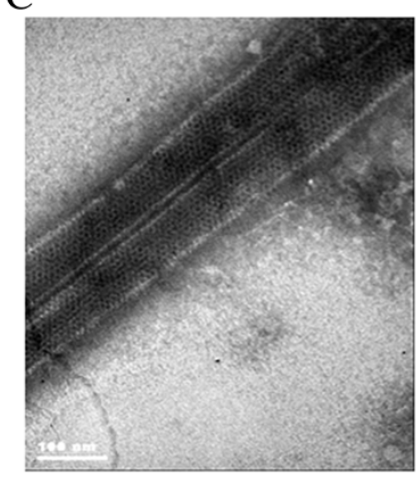

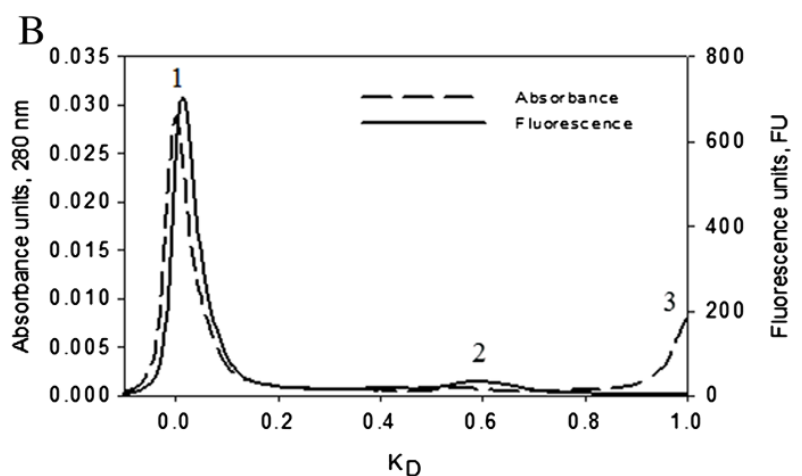

$\mathrm{D}$

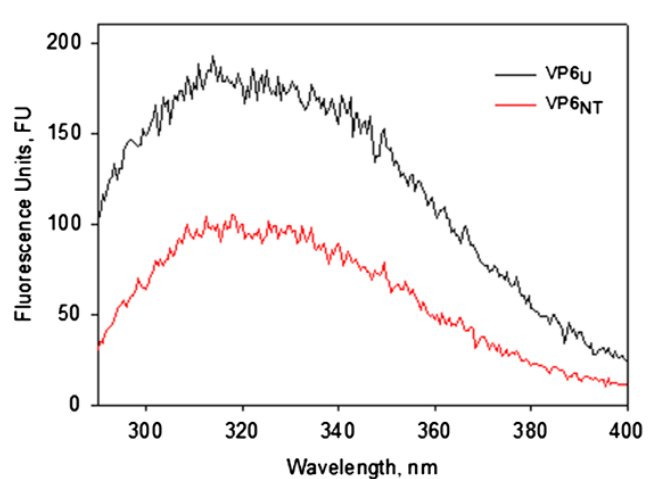

Figure 1 Characterization of purified $\mathbf{V P} \mathbf{6}_{\mathbf{N T}}$. A) 12\% SDS-PAGE gel stained with Coomassie Blue (under reducing conditions): Lane 1, Molecular weight marker Benchmark (Life Technologies Corp., Carlsbad, CA, USA), the more intense band corresponds to 50 KDa. Lane 2, VP6 NT. B) Size exclusion chromatography, Peak 1 corresponds to $V P 6_{N T}$, peak 2 to $V P 6_{U}$ and peak 3 to salts. $K_{D}$ refers to the relative elution volume calculated with Equation 1. C) Transmission electronic micrograph at 85,000X. D) Intrinsic fluorescence spectrum of $40 \mathrm{\mu g} / \mathrm{mL}$ of $V P 6_{N T}$ or $V P 6_{U}$. Excitation at $280 \mathrm{~nm}$.

experiments also showed that $\mathrm{VP} 6_{\mathrm{NT}}$ are more resistant to oxidation than $\mathrm{VP} 6_{\mathrm{U}}$. While the $\mathrm{VP}_{\mathrm{U}}$ band disappeared after exposure to $10,000 \mu \mathrm{M}$ of $\mathrm{H}_{2} \mathrm{O}_{2}$ in $\mathrm{MCO}$ for $1 \mathrm{~h}$, no change was observed in $\mathrm{VP}_{\mathrm{NT}}$ when incubated under the same condition. Exposure of $\mathrm{VP} 6_{\mathrm{NT}}$ to high $\mathrm{H}_{2} \mathrm{O}_{2}$ concentrations for as much as six hours was needed for its band to disappear, suggesting a higher stability towards oxidative insults. The same behavior was observed in native gels (data not shown).

In order to further dissect the molecular impact of the oxidative damage inflicted into VP6, the carbonyl content in $\mathrm{VP} 6_{\mathrm{U}}, \mathrm{VP} 6_{\mathrm{NT}}$, and BSA was measured after exposure to $\mathrm{MCO}$ at various $\mathrm{H}_{2} \mathrm{O}_{2}$ concentrations (Figure $3 \mathrm{~A}$ ). The initial carbonyl contents before oxidation were $0.069 \pm 0.023 \mathrm{molc} / \mathrm{molp}$ for $\mathrm{VP} 6_{\mathrm{NT}}, 0.059 \pm 0.023 \mathrm{molc} /$ molp for $\mathrm{VP}_{\mathrm{U}}$ and $0.167 \pm 0.010 \mathrm{molc} / \mathrm{molp}$ for BSA. Carbonyl content increased in all samples as $\mathrm{H}_{2} \mathrm{O}_{2}$ concentration increased, following a saturation curve. Results shown in Figure 3A were obtained maintaining the $\mathrm{Fe}^{+2}$ concentration constant at $150 \mu \mathrm{M}$ while increasing $\mathrm{H}_{2} \mathrm{O}_{2}$ concentration to excess. This condition can result in the formation of oxidative species other than $\cdot \mathrm{OH}$, such as the remaining $\mathrm{H}_{2} \mathrm{O}_{2}$ or $\bullet \mathrm{OOH}[8,12]$. In order to restrict the formation of $\mathrm{ROS}$ to the $\cdot \mathrm{OH}$ radical, the
Fenton reaction was performed at equimolar concentrations of $\mathrm{Fe}^{+2}$ and $\mathrm{H}_{2} \mathrm{O}_{2}$ (Figure 3B). The carbonyl content under this condition was 64 times higher for $\mathrm{VP}_{\mathrm{U}}$ and 5 times higher for $\mathrm{VP}_{\mathrm{NT}}$ than when $\mathrm{Fe}^{+2}$ concentration remained constant. It also followed a saturation curve.

Data sets were adjusted to the following equation describing a saturation curve:

$$
[c]=\frac{[c]_{\max }\left[H_{2} \mathrm{O}_{2}\right]}{a+\left[\mathrm{H}_{2} \mathrm{O}_{2}\right]}
$$

where $[c]$ is the carbonyl content (molc/molp), $[c]_{\text {max }}$ is the maximum carbonyl content, and $a$ is a saturation constant. The values of the equation constants for each condition are listed in Table 1. The specific carbonyl content at saturation with constant $\mathrm{Fe}^{+2}$ was two times higher in $\mathrm{VP}_{\mathrm{U}}$ than in $\mathrm{VP} 6_{\mathrm{NT}}$, whereas $[c]_{\max }$ was similar for BSA and $\mathrm{VP6}_{\mathrm{U}}$. In an analogy with enzyme kinetics, protein susceptibility to oxidation (affinity towards the oxidant) can be inferred from $a$. BSA was the most susceptible to oxidation, while the susceptibility of $\mathrm{VP}_{\mathrm{NT}}$ to oxidation was two times higher than the susceptibility of $\mathrm{VP}_{\mathrm{U}}$. At equimolar $\mathrm{Fe}^{+2}$ and $\mathrm{H}_{2} \mathrm{O}_{2}$ concentrations, a 


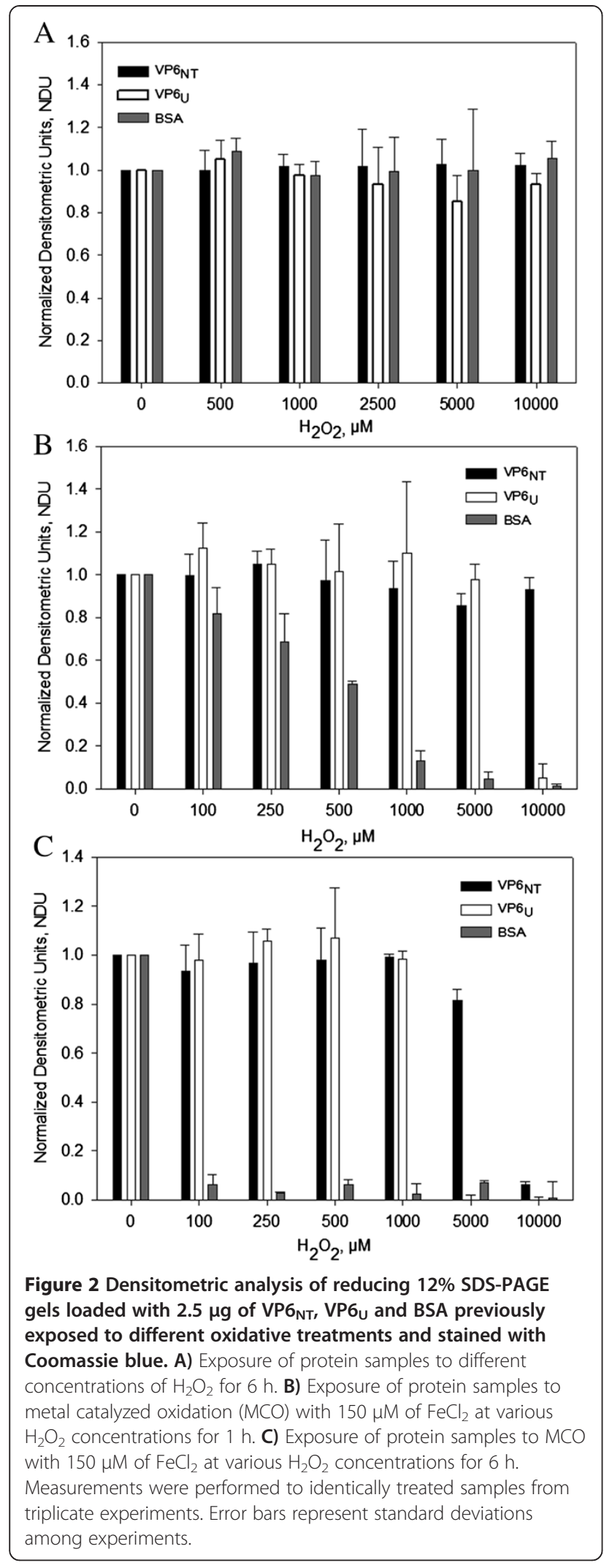

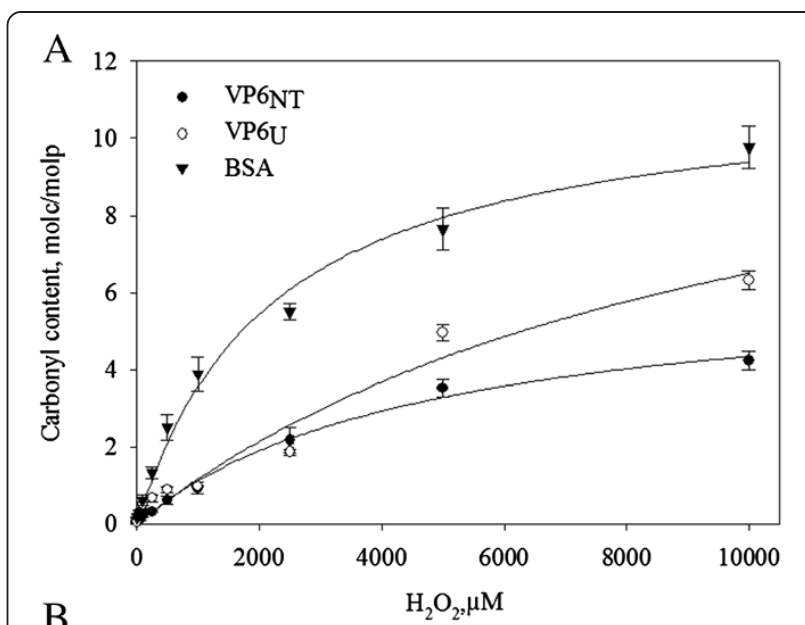

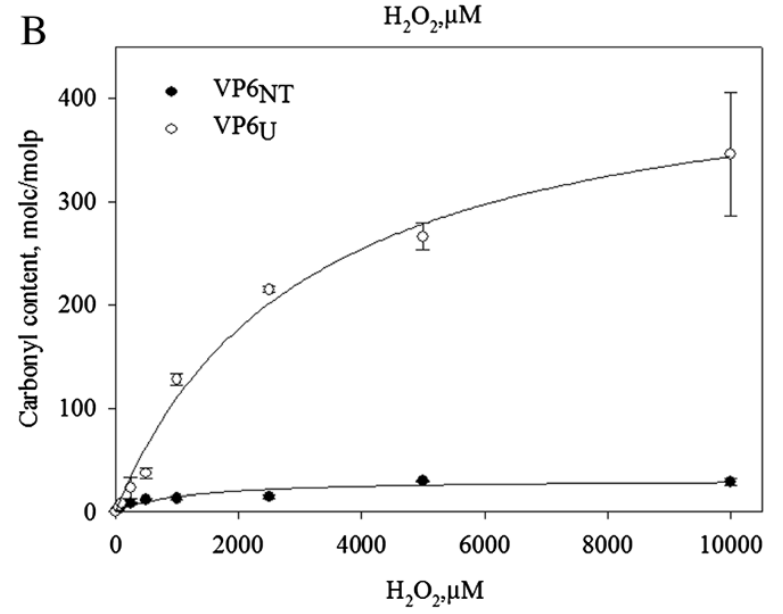

Figure 3 Carbonyl content on $\mathrm{VP}_{\mathrm{NT}}$ and $\mathrm{VP} 6_{\mathrm{U}}$ after MCO.

A) MCO was performed with $150 \mu \mathrm{M}$ of $\mathrm{FeCl}_{2}$ and different $\mathrm{H}_{2} \mathrm{O}_{2}$ concentrations for $1 \mathrm{~h}$. Experiments were performed in triplicate and error bars represent the standard deviation between them. B) MCO with equimolar concentrations of $\mathrm{FeCl}_{2}$ and $\mathrm{H}_{2} \mathrm{O}_{2}$. Experiments were performed in duplicate, error bars represent the difference between them. Lines show the behavior described by equation (1) using the parameters listed in Table 1 for each condition.

similar behavior was observed, where $[c]_{\max }$ and $a$ were 14 and 2.6 times higher in $\mathrm{VP}_{\mathrm{U}}$ than in $\mathrm{VP}_{\mathrm{NT}}$, respectively.

\section{Oxidation produced aggregation of $\mathrm{VP}_{\mathrm{U}}$ and} fragmentation of $\mathrm{VP}_{\mathrm{NT}}$

Oxidized samples of $\mathrm{VP}_{\mathrm{NT}}$ and $\mathrm{VP} 6_{\mathrm{U}}$ were analyzed by dynamic light scattering (DLS), transmission electron microscopy (TEM), SEC and spectrometry. The size of $\mathrm{VP6}_{\mathrm{NT}}$, measured by DLS, decreased as peroxide concentration increased (Figure 4A). The mean hydrodynamic diameter of nanotubes, which was $1,067.0 \pm 206.6 \mathrm{~nm}$ (corresponding to an equivalent sphere) without oxidation, decreased down to $317.5 \pm 40.4 \mathrm{~nm}$ after exposition to $10,000 \mu \mathrm{M} \mathrm{H}_{2} \mathrm{O}_{2}$. TEM showed that oxidation provoked the disassembly of nanotubes and aggregation of the resultant unassembled VP6 (Figure 5B). In contrast, oxidation of $\mathrm{VP}_{\mathrm{U}}$ resulted in an increase in size, 
Table 1 Coefficients in Equation 1 obtained by fitting carbonyl content at different $\mathrm{H}_{2} \mathrm{O}_{2}$ concentrations

\begin{tabular}{|c|c|c|c|}
\hline Sample & {$[\mathrm{c}]_{\max }, \mathrm{molc} / \mathrm{molp}$} & $\mathrm{a}, \mu \mathrm{M}$ & $r^{2}$ \\
\hline \multicolumn{4}{|c|}{ At constant $\left[\mathrm{Fe}^{+2}\right]$ and various $\left[\mathrm{H}_{2} \mathrm{O}_{2}\right]$ (Figure $3 \mathrm{~A}$ ) } \\
\hline VP6 $6_{N T}$ & $6.40 \pm 0.43$ & $4,745.99 \pm 681.64$ & 0.99 \\
\hline VP6u & $13.28 \pm 3.72$ & $10,431.12 \pm 4824.19$ & 0.97 \\
\hline BSA & $11.47 \pm 0.61$ & $2,216.32 \pm 324.21$ & 0.99 \\
\hline
\end{tabular}

With equimolar $\mathrm{H}_{2} \mathrm{O}_{2} / \mathrm{Fe}^{+2}$ concentrations (Figure 3B)

$\begin{array}{llll}\text { VP6 }_{\mathrm{NT}} & 31.49 \pm 4.16 & 1,154.85 \pm 499.22 & 0.89\end{array}$

$\begin{array}{llll}\text { VP6u } & 448.73 \pm 32.19 & 3,064.28 \pm 546.32 & 0.99\end{array}$

Data were fitted using the software SigmaPlot 10.0 (Systat Software, Inc., SJ, CA, USA). Coefficient standard errors are shown.

from a hydrodynamic diameter of $7.5 \pm 2.6 \mathrm{~nm}$ to $2,085.0 \pm 289.7 \mathrm{~nm}$ after exposition to $10,000 \mu \mathrm{M}$ of $\mathrm{H}_{2} \mathrm{O}_{2}$ (Figure 4B). TEM showed that the increase in size of oxidized $\mathrm{VP}_{\mathrm{U}}$ was caused by aggregation (Figure $5 \mathrm{C}$ ).

Another consequence of protein oxidation is dityrosine formation [30], which could have caused the aggregation observed in both types of VP6 assemblies. No dityrosines were detected in either $\mathrm{VP} 6_{\mathrm{NT}}$ or $\mathrm{VP} 6_{\mathrm{U}}$ (data not shown), indicating that aggregation was caused by other mechanisms, such as hydrophobic interactions or hydrogen bonding $[31,32]$.
To further understand the effect of oxidation in $\mathrm{VP}_{\mathrm{NT}}$, oxidized samples were analyzed by SEC, as previously described [29,33]. Absorbance at $280 \mathrm{~nm}$ and fluorescence of aromatic amino acids were followed (Figure 6). No changes in absorbance at $280 \mathrm{~nm}$ were observed in chromatograms when $\mathrm{VP} 6_{\mathrm{NT}}$ were oxidized with up to $1 \mathrm{mM}$ of $\mathrm{H}_{2} \mathrm{O}_{2}$ (Figure 6A). Such a result was expected, as DLS analysis showed that the products of oxidation, although smaller than nanotubes, were larger than the column pore size $(50 \mathrm{~nm})$. However, no absorbance was detected after oxidation with $10 \mathrm{mM} \mathrm{H}_{2} \mathrm{O}_{2}$. In contrast with absorbance, fluorescence of aromatic amino acids decreased as $\mathrm{H}_{2} \mathrm{O}_{2}$ concentration increased. Fluorescence decreased $40 \%$ upon oxidation with $100 \mu \mathrm{M}$ of $\mathrm{H}_{2} \mathrm{O}_{2}$, and consistently decreased until it completely disappeared at $10 \mathrm{mM}$ (Figure 6B). Additional peaks were observed at $1 \mathrm{mM}$ of $\mathrm{H}_{2} \mathrm{O}_{2}$, possibly smaller degradation products not detectable by absorbance.

Oxidation provoked changes in fluorescence intensity and in the center of fluorescence spectral mass (CSM)

Fluorescence emission spectra (290 nm to $600 \mathrm{~nm}$ ) of $\mathrm{VP}_{\mathrm{U}}$ and $\mathrm{VP} 6_{\mathrm{NT}}$ subjected to MCO were recorded for Tyr/Trp $\left(\lambda_{\text {ex }} 280 \mathrm{~nm}\right.$, data not shown) and $\operatorname{Trp}\left(\lambda_{\text {ex }}\right.$ $295 \mathrm{~nm}$, Figure 7A and B). Fluorescence of both VP6

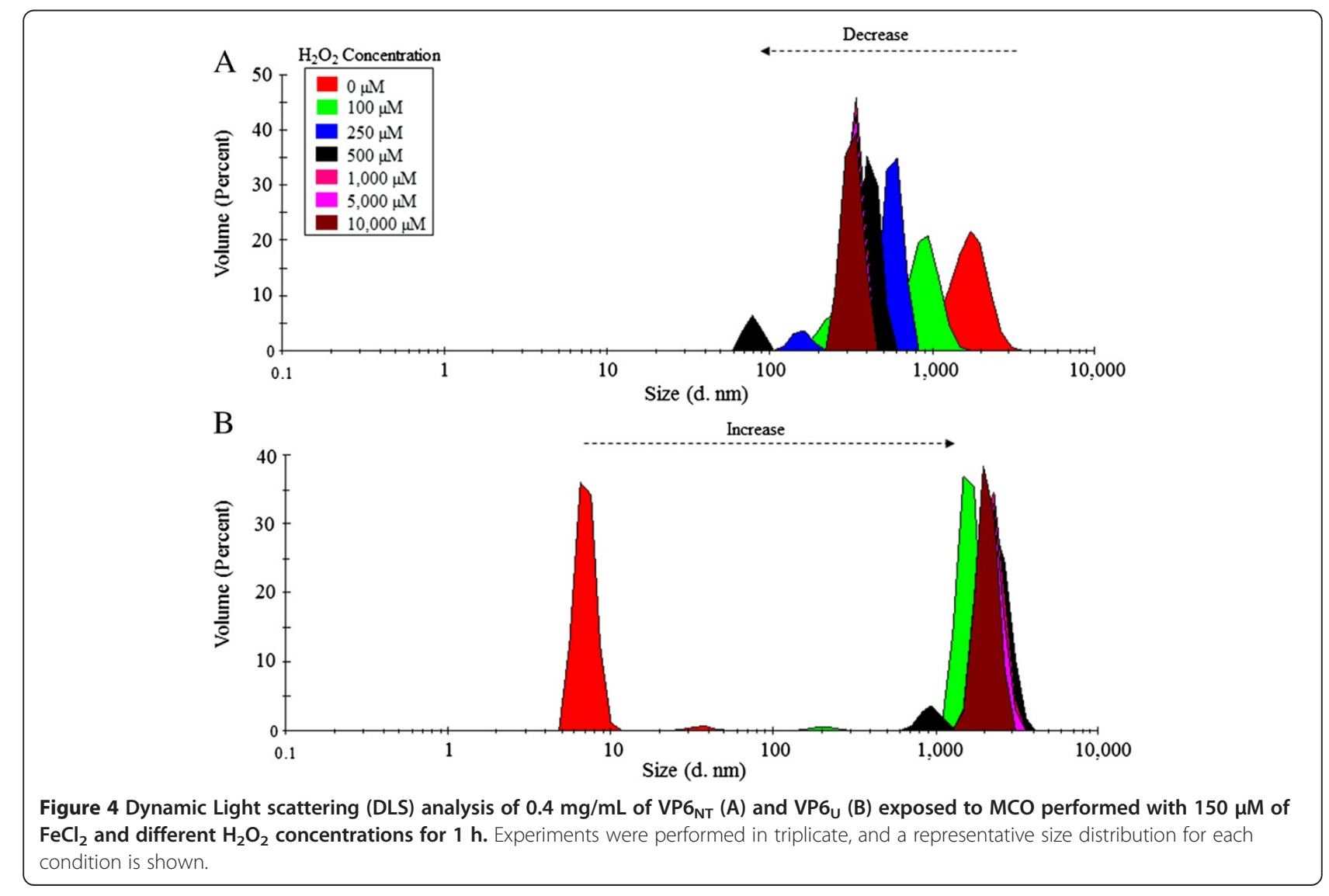




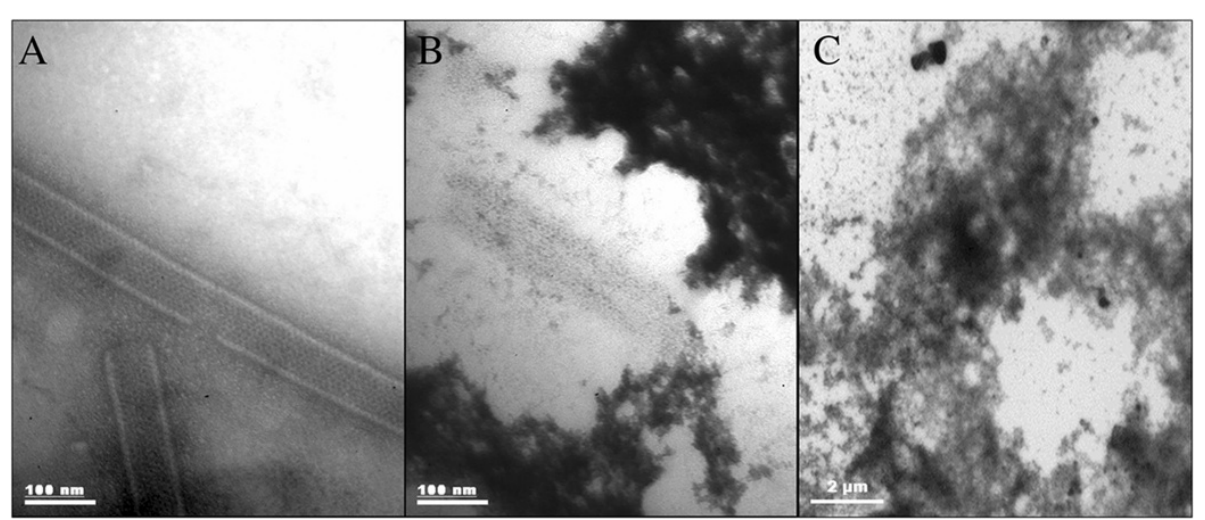

Figure 5 Transmission electronic microscopy (TEM) of VP6 $(0.4 \mathrm{mg} / \mathrm{mL})$ after $\mathrm{MCO}$ at $10,000 \mu \mathrm{M}$ of $\mathrm{H}_{2} \mathrm{O}_{2}$ and $150 \mu \mathrm{M}$ of $\mathrm{FeCl}_{2}$ for $1 \mathrm{~h}$. Samples were stained with $2 \%$ uranyl acetate. A) Untreated VP6 $6_{N T}$. B) Oxidized VP6 $6_{N T}$ sample. C) Oxidized VP6u sample.

and $\mathrm{VP} 6_{\mathrm{NT}}$ decreased as the concentration of $\mathrm{H}_{2} \mathrm{O}_{2}$ increased. Fluorescence decreased the most at $\mathrm{H}_{2} \mathrm{O}_{2}$ concentrations above $0.1 \mathrm{mM}$, where it diminished at least $50 \%$ in all cases. Fluorescence of $\mathrm{VP}_{\mathrm{NT}}$ had a more pronounced decrease than fluorescence of $\mathrm{VP} 6_{\mathrm{U}}$, disappearing at $\mathrm{H}_{2} \mathrm{O}_{2}$ concentrations above $250 \mu \mathrm{M}$.

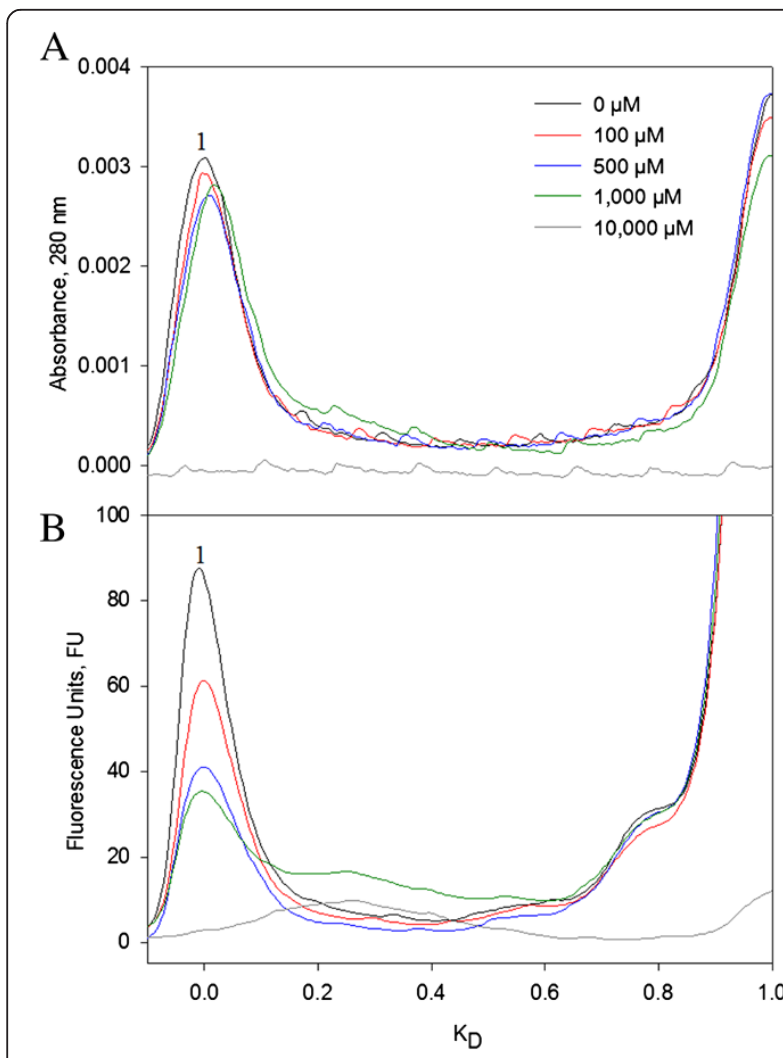

Figure 6 Size exclusion chromatography of $\mathrm{VP}_{\mathrm{NT}}$ samples $\left(0.4 \mathrm{mg} / \mathrm{mL}\right.$ ) after $\mathrm{MCO}$ with $150 \mu \mathrm{M}$ of $\mathrm{FeCl}_{2}$ at various $\mathrm{H}_{2} \mathrm{O}_{2}$ concentrations for 1 h. A) Absorbance elution profile at $280 \mathrm{~nm}$. B) Fluorescence elution profile at $\lambda_{\text {ex }} 280 \mathrm{~nm}$ and $\lambda_{\mathrm{em}} 350 \mathrm{~nm}$. Peak 1 corresponds to VP6 $6_{\mathrm{NT}}$. Experiments were performed in duplicate and a representative size distribution for each condition is shown.
The center of fluorescence spectral mass (CSM) was calculated for each spectra (Figure 7C). For comparison, the CSM of VP6 treated for $1 \mathrm{~h}$ with $6 \mathrm{M}$ guanidine chloride, an unfolded control, is shown at the right of the figure $\left(\mathrm{CSM}=27,642 \pm 136 \mathrm{~cm}^{-1}\right)$. For both VP6 forms, the CSM decreased as the $\mathrm{H}_{2} \mathrm{O}_{2}$ concentration increased up to $1 \mathrm{mM}$, and reached wavelengths comparable to that of the unfolded control. At higher $\mathrm{H}_{2} \mathrm{O}_{2}$ concentrations, CSM of $\mathrm{VP}_{\mathrm{U}}$ consistently increased.

\section{Efficiency assembly of $\mathrm{VP} 6_{\mathrm{NT}}$ decreased after oxidation}

Oxidized $\mathrm{VP}_{\mathrm{U}}$ at various $\mathrm{H}_{2} \mathrm{O}_{2}$ concentrations was subjected to in vitro assembly conditions to determine if oxidation impedes its assembly into VP6 $6_{\mathrm{NT}}$. Samples incubated for $6 \mathrm{~h}$ were analyzed by SEC to determine the relative concentration of assembled VP6, which elutes with the void volume of the SEC column $\left(K_{D}=0\right)$ (Figure 8A). A sample of $\mathrm{VP6}_{\mathrm{U}}$ not treated for assembly is shown for comparison. $\mathrm{VP}_{U}$ eluted at a $\mathrm{K}_{\mathrm{D}}$ of 0.6 . The peak corresponding to $\mathrm{VP}_{\mathrm{U}}$ disappeared in all samples treated for assembly, and peaks appeared at lower $\mathrm{K}_{\mathrm{D}}$. The abundance of the peak corresponding to ${ }^{V P 6} 6_{N T}$ decreased as $\mathrm{H}_{2} \mathrm{O}_{2}$ concentration increased. Assembly efficiencies were determined by SEC and calculated by dividing the area of the peak at $0 \mathrm{~K}_{\mathrm{D}}$ (corresponding to $\mathrm{VP} 6_{\mathrm{NT}}$ ) by the total peak area below 0.8 $K_{D}$, to exclude the salt peak (Figure $8 \mathrm{~A}$ ). $\mathrm{VP}_{\mathrm{U}}$ before being subjected to the assembly reactions is shown for comparison. Untreated VP6 assembled into VP6 $6_{\mathrm{NT}}$ with a $72 \%$ efficiency. Nanotubes with the expected characteristic were observed by TEM (Figure 9A). The assembly efficiency of oxidized $\mathrm{VP}_{\mathrm{U}}$ decreased as $\mathrm{H}_{2} \mathrm{O}_{2}$ concentration increased (Figure $8 \mathrm{~B}$ ), and the quality of the assembled $\mathrm{VP}_{\mathrm{NT}}$ decreased (Figure 9B to F). It was increasingly difficult to find assembled nanotubes as the $\mathrm{H}_{2} \mathrm{O}_{2}$ concentration increased, and those found had various defects, such as fractures, incomplete NT and association with aggregates (Figure 9B to F). Most likely 

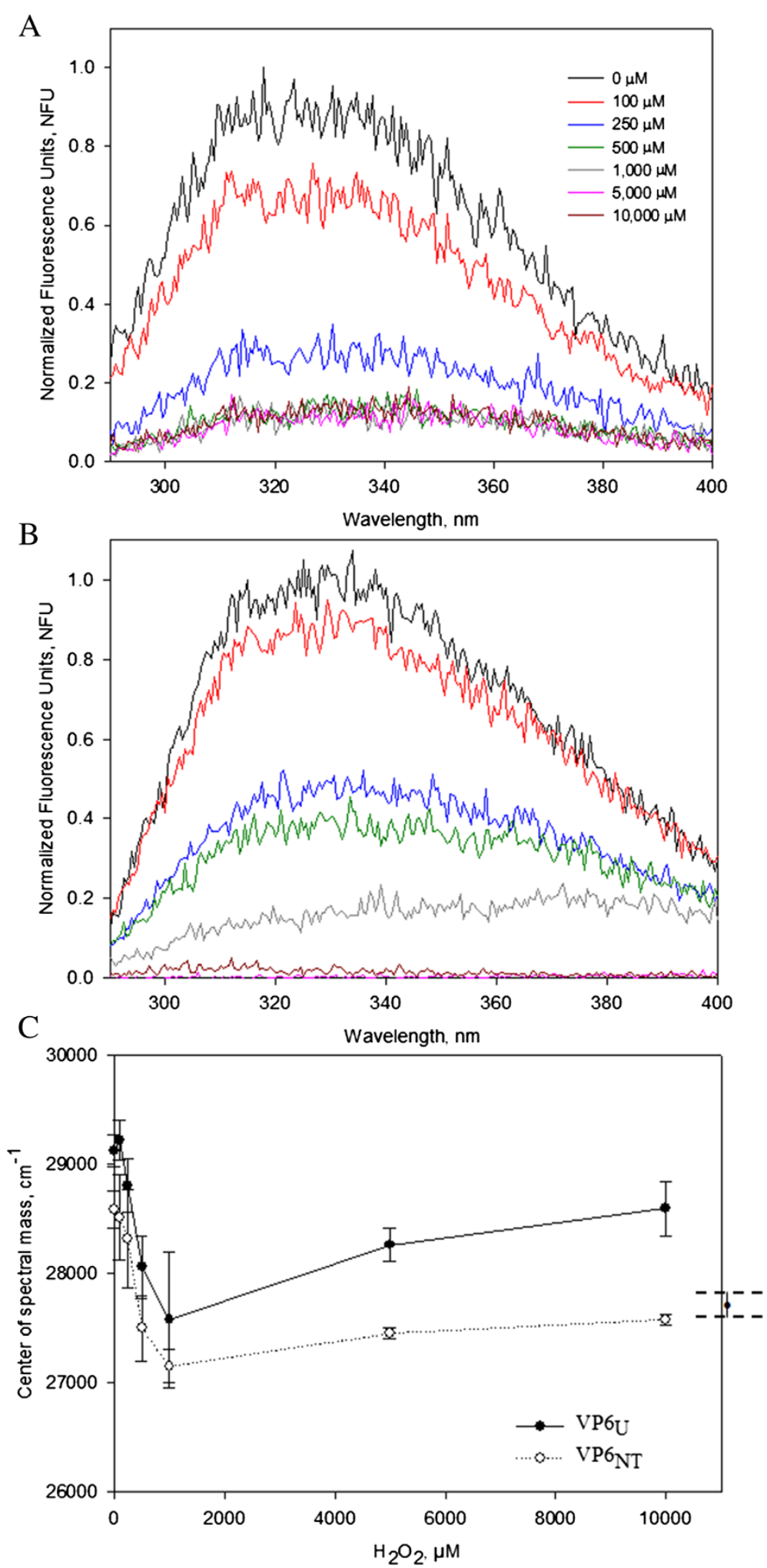

Figure 7 Emission fluorescence scans at $\lambda_{\mathrm{ex}} 295 \mathrm{~nm}$ of $\mathrm{VP} 6_{\mathrm{NT}}$ and VP6U $(0.4 \mathrm{mg} / \mathrm{mL})$ after $\mathrm{MCO}$ with $150 \mu \mathrm{M}$ of $\mathrm{FeCl}_{2}$ at various $\mathrm{H}_{2} \mathrm{O}_{2}$ concentrations for $1 \mathbf{h}$. A) Normalized emission spectra of $\mathrm{VPG}_{\mathrm{NT}}$. B) Normalized emission spectra of $\mathrm{VP6} 6_{U}$. C) The center of spectral mass (CSM) of oxidized $V P 6_{N T}$ and $V P 6_{U}$ was calculated using Equation (3) and plotted against the $\mathrm{H}_{2} \mathrm{O}_{2}$ concentration used. On the right, the CSM of denatured VP6 (treated for 2 hours with $6 \mathrm{M}$ of guanidine chloride) is shown for comparison. Experiments were performed in triplicate, except for the CSM of denatured VP6, which was analyzed in duplicate. Error bars represent the standard deviation or difference among them. 

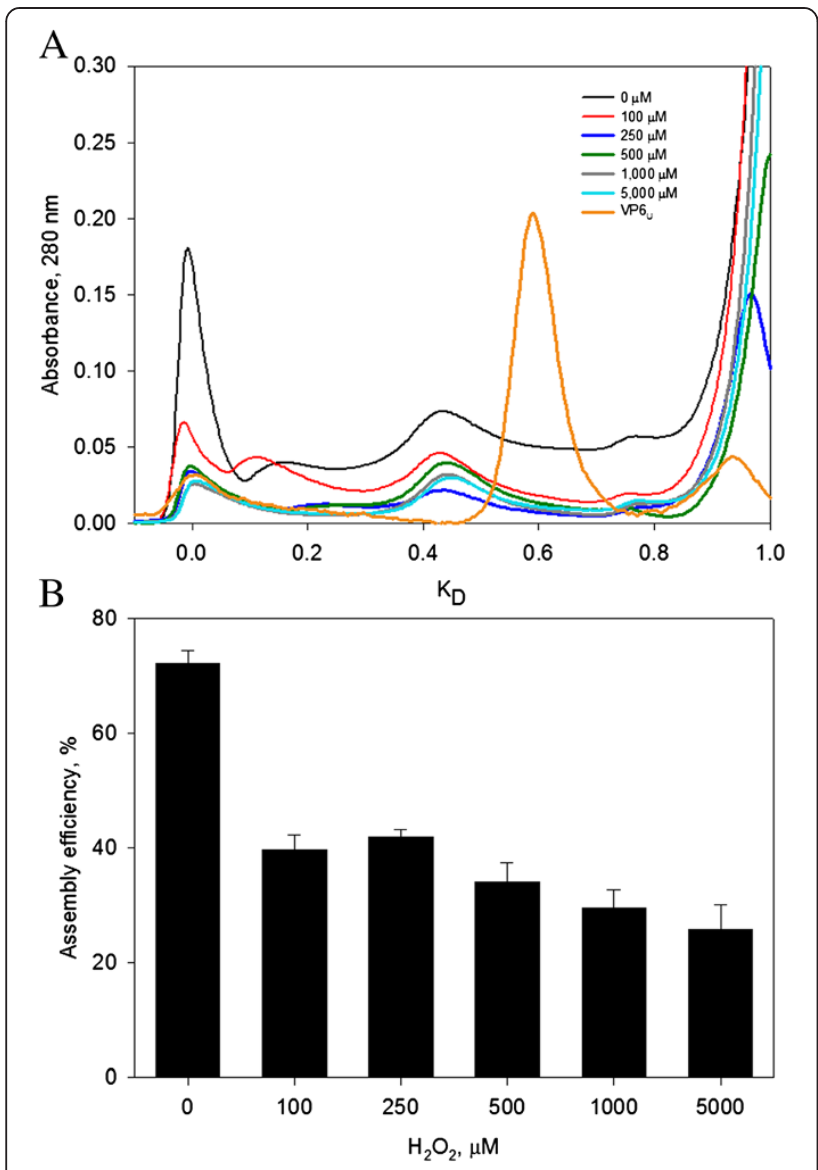

Figure 8 Assembly efficiency of VP6 exposed to MCO for $\mathbf{1 ~ h}$ $\left(150 \mu \mathrm{M}\right.$ of $\left.\mathrm{FeCl}_{2}\right) .1 \mathrm{mg}$ of $\mathrm{VPG} \cup$ at $0.4 \mathrm{mg} / \mathrm{mL}$ was subjected to assembly conditions. A) SEC of samples of VP6 after incubation at the assembly conditions. For comparison, a chromatogram of VP6u is also shown. B) Assembly efficiencies calculated from chromatograms in A. Assembly efficiencies were calculated as the area under the curve of peak 1 of each chromatogram divided by the total area below the curve at $K_{D}$ lower or equal to 0.8 . Experiments were performed in duplicate, difference between duplicates is represented by error bars.

the assembly efficiency was overestimated, as aggregation of $\mathrm{VP}_{\mathrm{U}}$ upon oxidation was observed.

\section{Discussion}

The importance of oxidation in the integrity of macromolecules has been widely recognized [7]. However, only one previous article has reported the effect of oxidation in a VLP, focusing mostly on the immunogenicity of a vaccine [24]. To study the effect of oxidation on protein assemblies, rotavirus VP6 in two forms, unassembled and assembled into nanotubes, was subjected to oxidation. BSA, a widely studied protein, was treated in parallel for comparison. Protein degradation, carbonylation, size, appearance assessed by TEM, spectrophotometric characterization, and assembly efficiencies were evaluated to determine the effect of oxidation on protein assemblies.
The experiments performed here showed that BSA is less resistant to oxidation than VP6. BSA was degraded by $\mathrm{MCO}$ at lower $\mathrm{H}_{2} \mathrm{O}_{2}$ concentrations and shorter times than VP6. Degradation of BSA by oxidation has been previously observed in SDS-PAGE gels similar to those shown here [15]. Protein degradation is a consequence of peptide bond cleavage. It has been proposed that $\alpha$-amidation and diamide formation are the main mechanisms of peptide bond rupture under oxidative conditions [34-36].

Protein carbonylation is the most destructive irreversible modification caused by oxidation. It is also an excellent biomarker of oxidative stress because of its early formation and stability $[37,38]$. BSA was less resistant to carbonylation than VP6. Carbonyl contents found here were similar to those previously reported for BSA [15,36]. The higher susceptibility of BSA to damage by oxidation is probably the result of its higher content of lysine, arginine, proline and threonine (RKPT), 149 residues/mol, in comparison with the 82 residues/mol in VP6. The side chains of RPKT amino acids are the most important precursors of carbonylated compounds [34,39]. The constants obtained from data fitting to Equation 1 provide information about the carbonyl content at $\mathrm{H}_{2} \mathrm{O}_{2}$ saturation and the susceptibility of the protein to carbonylation. At $150 \mu \mathrm{M}$ of $\mathrm{Fe}^{+2}$ and $10,000 \mu \mathrm{M}$ of $\mathrm{H}_{2} \mathrm{O}_{2}$, the carbonyl content in BSA was close to saturation. Also, the value of $a$ for BSA was the lowest, in accordance with the experimental observations that BSA was less resistant to oxidation than VP6 in either of its assembled forms. In addition to its higher number of RKPT residues, BSA has 35 cysteines, forming 17 disulfide bonds, while VP6 has only 8 cysteines and no disulfide bonds. Cysteines are also highly susceptible to oxidation, forming a wide variety of compounds [40].

The fluorescence emission of unassembled and assembled VP6 showed that the microenvironment of Tyr and Trp residues are different in both assemblies. The quantum yield of $\mathrm{VP}_{\mathrm{U}}$ was twice that of $\mathrm{VP} 6_{\mathrm{NT}}$, possibly because Trp residues are exposed to the solvent only in $\mathrm{VP}_{\mathrm{U}}$ (as visualized from the crystal structure reported previously [26]). While for $\mathrm{VP}_{U}$, the Tyr and Trp residues exposed to the solvent are 18 and 8 , respectively, for $\mathrm{VP} 6_{\mathrm{NT}}$ only 3 Tyr are exposed [25].

The experiments performed here show that the extent of oxidation of assembled VP6 lower than that of $\mathrm{VP} 6_{\mathrm{U}}$, suggesting that number of oxidizable amino acids that are exposed to the solvent is more important for overall protein oxidation than chain reactions that can be triggered by ROS and propagate the damage to the protein assembly. VP6 assembly into nanotubes may result in additional protection to VP6, as the VP6 nanotube lumen is not freely accessible to ions [28]. In the two sets of carbonylation reactions performed, $\mathrm{VP}_{\mathrm{U}}$ had the highest maximum carbonyl content, supporting the idea 


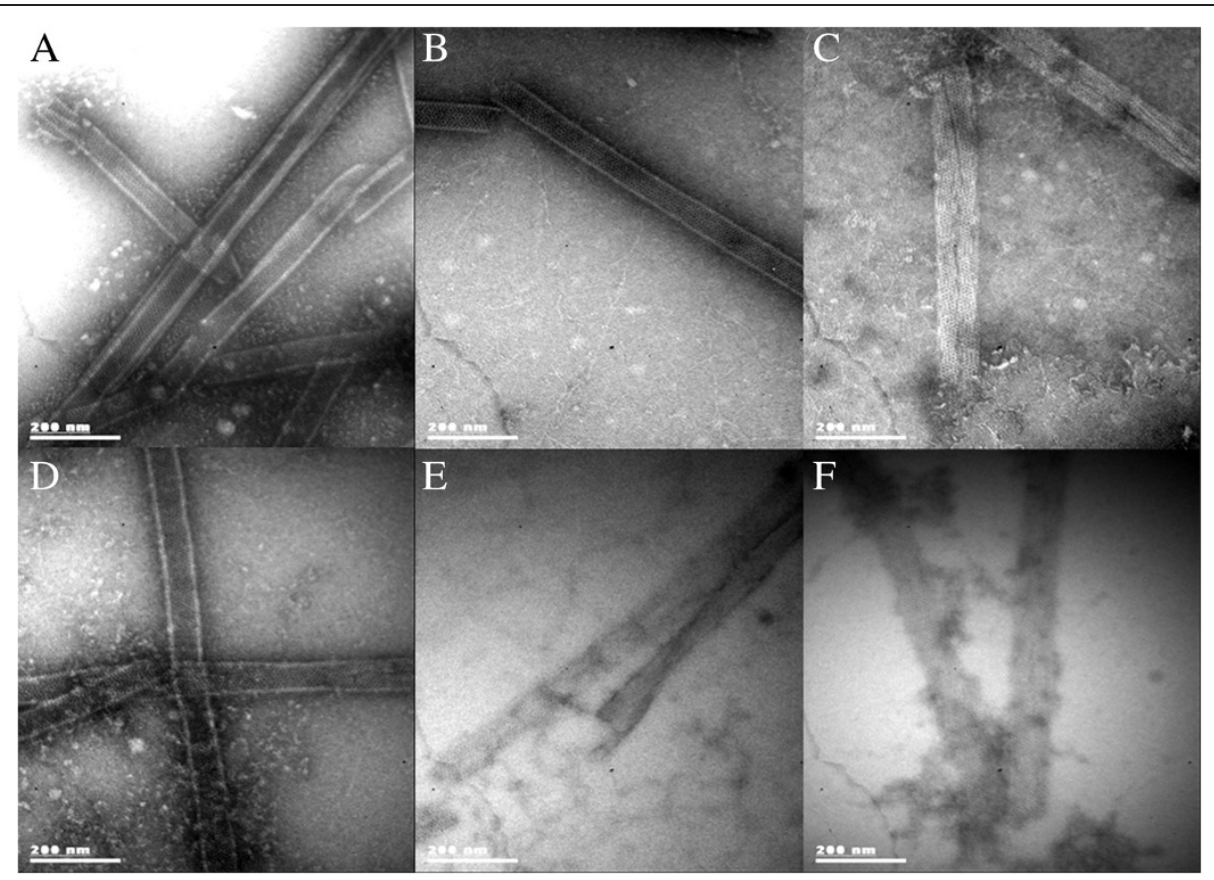

Figure 9 TEM micrographs of VP6u subjected to assembly conditions after exposure for $\mathbf{1} \mathbf{h}$ to $\mathbf{M C O}$. A) Nanotubes obtained after

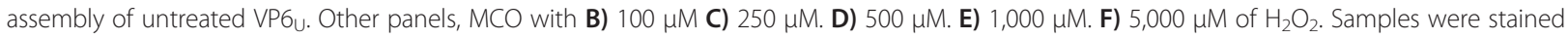
with $2 \%$ uranyl acetate and observed at a magnification of $85,000 \mathrm{X}$.

that a higher protein area exposed to the solvent results in more oxidation. However, the value of $a$ from Equation 1 was lower for $\mathrm{VP} 6_{\mathrm{NT}}$, indicating that even when fewer amino acids were oxidized, they were more readily accessible to ROS. The higher susceptibility of $\mathrm{VP}_{\mathrm{NT}}$ to oxidation was accompanied by a steeper decrease in fluorescence, suggesting that the aromatic amino acids exposed to the surface were the more susceptible to oxidation. The maximum carbonyl content obtained in $\mathrm{VP}_{\mathrm{U}}$ was similar to the number of amino acids in VP6. As certain amino acids are more susceptible to carbonylation than others, this suggests that each oxidized amino acid generated more than one carbonyl group.

DLS analysis showed that oxidation provoked the disassembly of $\mathrm{VP}_{\mathrm{NT}}$ and the aggregation of $\mathrm{VP}_{\mathrm{U}}$, probably caused by carbonylation. Changes in hydrophobicity due to carbonylated amino acid residues induce protein aggregation [38]. Also, accumulation of oxidized dysfunctional proteins with reactive carbonyl groups can lead to interand intramolecular cross-links with amino groups [41]. No formation of dityrosines was found, indicating that aggregation had a different cause, possibly hydrophobic interactions, hydrogen bonding or free thiol groups cross-linking [31,32]. Aggregation and nanotube disassembly have important impacts on possible applications of $\mathrm{VP}_{\mathrm{NT}}$. Aggregation has been linked with protein immunogenicity [42], and nanotubes are required for the use of VP6 as an efficient vaccine or as a delivery vehicle
$[2,43]$. Interestingly, MCO of HBsAg VLP did not produce aggregation even at higher oxidant concentrations (100 mM of $\mathrm{H}_{2} \mathrm{O}_{2}$ and $100 \mu \mathrm{M}$ of $\mathrm{Fe}^{+2}$ ) than those evaluated in the present work.

Fluorescence emission spectra drastically changed upon oxidation of both VP6 forms. Fluorescence emission decreased as $\mathrm{H}_{2} \mathrm{O}_{2}$ concentration increased. Similar results were described by Davies and coworkers [17], who observed fluorescence quenching of aromatic amino acids, mainly Trp, after oxidation with $\bullet \mathrm{OH}$ and $\bullet \mathrm{OH}+\mathrm{O}_{2}{ }^{-}$radicals. Oxidative damage to proteins includes oxidation of aromatic rings, resulting in non-fluorescent derivatives [44]. CSM also decreased as $\mathrm{H}_{2} \mathrm{O}_{2}$ increased up to $1 \mathrm{mM}$ of $\mathrm{H}_{2} \mathrm{O}_{2}$, moving towards the CSM of the unfolded VP6 control, most likely caused by a partial denaturation of VP6 [45,46]. The CSM at $295 \mathrm{~nm}$ correlates with the microenvironment surrounding Trp residues, which can be in a relaxed structure (hydrophilic, lower CSM values) or in a compact structure (hydrophobic, higher CSM values) [45,47]. The CSM of $\mathrm{VP}_{\mathrm{NT}}$ remained lower than that of $\mathrm{VP}_{\mathrm{U}}$ at all conditions tested, indicating that aromatic amino acids remained in a more hydrophilic environment in $\mathrm{VP}_{\mathrm{NT}}$ than in $\mathrm{VP}_{\mathrm{U}}$. CSM of both VP6 forms increased at $\mathrm{H}_{2} \mathrm{O}_{2}$ concentrations above $1 \mathrm{mM}$, probably as a result of aggregation.

Oxidation decreased the assembly capacity of $\mathrm{VP}_{\mathrm{U}}$ by about half, even at only $100 \mu \mathrm{M}$ of $\mathrm{H}_{2} \mathrm{O}_{2}$. All the modifications provoked by oxidation described above can result in 
a lower assembly efficiency of VP6. Either conformational changes or modification of the amino acids in intratrimer or intertrimer regions can impede assembly. For example, Erk and coworkers [48] replaced the His 153 of VP6 with Ser, resulting in a protein that can assemble into trimers but not into nanotubes. Moreover, aggregation provoked by oxidation can also reduce the assembly efficiency into nanotubes. Interestingly, oxidation resulted in nanotubes that had several defects, indicating that even when oxidized VP6 could assemble, the resulting assemblies were less stable. The results obtained highlight the importance of impeding oxidation during the production, purification and storage of protein assemblies and their subunits.

\section{Conclusions}

In this work, the role of oxidation on multimeric protein assembly was described for the first time. Differential effects of the susceptibility of oxidation of a protein assembled or unassembled were found. The results presented here show that oxidation can cause important changes to assembled and unassembled VP6, affecting the protein functionality. In vitro assembly of $\mathrm{VP}_{\mathrm{U}}$ to form $\mathrm{VP} 6_{\mathrm{NT}}$ decreased with oxidation, evidencing that ROS have to be minimized during the production process when $\mathrm{VP} 6_{\mathrm{NT}}$ are needed. In vitro studies of protein oxidation are useful tools for development of new bioprocess to reduce the impact of oxidation on therapeutic proteins produced in heterologous systems. The results of this work show that oxidation must to be avoided in all production stages, including upstream, downstream, handling and storage.

\section{Methods}

\section{VP6 nanotube production, purification and characterization}

VP6 nanotubes were produced using the insect cellbaculovirus expression vector system (IC-BVS) as described before [29]. Briefly, High Five ${ }^{\odot}$ insect cells (Life Technologies, Carlsbad, CA, USA) were grown in $1 \mathrm{~L}$ shake flasks with $200 \mathrm{~mL}$ of Sf900II medium (Life Technologies, Carlsbad, CA, USA). Cells were infected at $1 \times 10^{6} \mathrm{cell} / \mathrm{mL}$ with a recombinant baculovirus (AcMNPV) that contains a rotavirus VP6 gene (strain SA11), at a multiplicity of infection (MOI) of 1 plaque forming unit (pfu)/cell. Infected cultures were harvested at 96 hours post infection (hpi) and centrifuged at $10,000 \times \mathrm{g}$ for 10 minutes. Clarified supernatants were concentrated by ultrafiltration using a nitrocellulose membrane with a $30 \mathrm{kDa}$ cut-off (Merck, Billerica, MA, USA). Purification of VP6 assembled as nanotubes $\left(\mathrm{VP}_{\mathrm{NT}}\right)$ was performed as described previously [29]. Total protein content was determined using the Bradford assay (Bio-rad Laboratories, Hercules, CA, USA) and sample purity was calculated from densitometry of reducing denaturing SDS-PAGE gels. VP6 identity was confirmed by Western blot using a polyclonal rabbit serum against NCDV rotavirus (1:4000 dilution in PBS-T), an anti-rabbit IgG-HRP antibody (Santa Cruz Biotechnology, Santa Cruz, CA, USA) (1:4,000 in PBS-T) and developed with carbazole. A prestained molecular weight marker, Dual Color, was used for Western blot experiments (Bio-rad Laboratories, Hercules, CA, USA).

The presence of VP6 assemblies, such as VP6 $6_{\mathrm{NT}}$, was detected by size exclusion HPLC (SEC) [29,33] in a Waters chromatographic system (Waters Corp., MA, USA) with an UV diode array detector at 205, 260 and $280 \mathrm{~nm}$ and a fluorescence detector set at $\lambda_{\mathrm{ex}} 280 \mathrm{~nm}$ and $\lambda_{\mathrm{em}} 350 \mathrm{~nm}$ (for aromatic amino acid fluorescence). Protein separation was performed using an Ultrahydrogel 500 size exclusion column (Waters Corp., MA, USA) with an isocratic flow of $0.9 \mathrm{~mL} / \mathrm{min}$ of Tris buffer $(10 \mathrm{mM}$, $\mathrm{pH}$ 8.0). The size exclusion column was calibrated with purified protein standards of lysozyme (hydrodynamic radius, $\left.R_{H}=1.8 \mathrm{~nm}\right)$, trypsinogen $\left(\mathrm{R}_{\mathrm{H}}=2.2 \mathrm{~nm}\right)$, green fluorescence protein $\left(R_{H}=2.4 \mathrm{~nm}\right)$, ovoalbumin $\left(R_{H}=2.8 \mathrm{~nm}\right)$, bovine serum albumin $\left(R_{H}=3.5 \mathrm{~nm}\right)$, mouse immunoglobulin G $(5.3 \mathrm{~nm})$, and $30 \mathrm{~nm}$ standard fluorospheres $\left(\lambda_{\mathrm{ex}}=505 \mathrm{~nm}, \lambda_{\mathrm{em}}=515 \mathrm{~nm}\right.$, Life Technologies, Carlsbad, $\mathrm{CA}, \mathrm{USA})$. The column void volume $\left(\mathrm{V}_{0}\right)$ was determined with $100 \mathrm{~nm}$ standard fluorospheres and the total column volume $\left(V_{t}\right)$ was determined with sodium azide. The partition coefficient $\left(\mathrm{K}_{\mathrm{D}}\right)$ of each protein was calculated using the following equation:

$$
K_{D}=\frac{V_{e}-V_{o}}{V_{t}-V_{o}}
$$

where $V_{e}$ is the elution volume of the protein peak.

The hydrodynamic size of $\mathrm{VP}_{\mathrm{NT}}$ was determined by dynamic light scattering (DLS) in a Zetasizer Nano (Malvern Inst. Ltd, Worcestershire, UK) at $173^{\circ}$ backscatter using a normal resolution mode. Sizes are reported as the diameter of the equivalent sphere of the particles analyzed. Samples for transmission electron microscopy (TEM) were placed over 200 mesh copper grids coated with Formvar-carbon (Structure Probe Inc., West Chester, PA, USA) and stained with 2\% uranyl acetate (Structure Probe Inc., West Chester, PA, USA) for $1 \mathrm{~min}$ and visualized in a Zeiss EM 900 transmission electron microscope (Carl Zeiss Microscopy GmbH, Jena, Germany) operated at $80 \mathrm{KV}$.

\section{Disassembly and assembly of VP6}

$\mathrm{VP}_{\mathrm{NT}}$ were disassembled by adding $300 \mathrm{mM}$ of $\mathrm{Ca}^{+2}$ and incubating for $6 \mathrm{~h}$ at $27^{\circ} \mathrm{C}$ with constant agitation in a Thermomixer Comfort (Eppendorf, Hauppauge, NY, USA) [33]. For reassembly, VP6 samples at $0.4 \mathrm{mg} / \mathrm{mL}$ were mixed with 10 volumes of $100 \mathrm{mM}$ sodium bicarbonate (Sigma Aldrich, St. Louis, USA) at $\mathrm{pH} 8.0$ to precipitate calcium and centrifuged at 5,000 rpm for $10 \mathrm{~min}$. 
Supernatants were collected and concentrated through a $30 \mathrm{kDa}$ cut-off membrane in an Amicon ultrafiltration device (Merck Millipore Corp, Billerica, MA, USA).

\section{Protein oxidation}

$\mathrm{VP}_{\mathrm{NT}}$ and $\mathrm{VP}_{\mathrm{U}}$ were oxidized with two oxidants, $\mathrm{H}_{2} \mathrm{O}_{2}$ (Fermont, Monterrey, Mexico) or $\bullet \mathrm{OH}$ (obtained through the Fenton reaction, $\mathrm{Fe}^{+2} / \mathrm{H}_{2} \mathrm{O}_{2}$ ), using various $\mathrm{H}_{2} \mathrm{O}_{2}$ concentrations (50, 100, 250, 500, 1,000, 2,500, $5,000$ and $10,000 \mu \mathrm{M})$. For the Fenton reaction, a constant concentration of $150 \mu \mathrm{M}$ of $\mathrm{Fe}^{+2}$ (as $\mathrm{FeCl}_{2}$, Sigma Aldrich, St. Louis, USA) was maintained, unless otherwise noted. In some experiments, $\mathrm{Fe}^{+2} / \mathrm{H}_{2} \mathrm{O}_{2}$ in equimolar concentrations were used. Oxidation with $\cdot \mathrm{OH}$ is referred as metalcatalyzed oxidation (MCO) throughout the text. Samples were incubated at $27^{\circ} \mathrm{C}$ for 1 and $6 \mathrm{~h}$. Oxidized $\mathrm{VP} 6_{\mathrm{NT}}$ and $\mathrm{VP6}_{\mathrm{U}}$ were analyzed by SDS-PAGE (denaturing and nondenaturing conditions), SEC, DLS and TEM. $2.5 \mu \mathrm{g}$ of protein were used for each MCO condition in SDS-PAGE experiments.

\section{Detection and quantification of protein carbonylation}

Protein carbonylation was detected by immunoblotting using the Oxyblot ${ }^{\mathrm{TM}}$ kit (Merck Millipore Corp, Billerica, MA, USA), following manufacturer instructions: $1 \mu \mathrm{g}$ of protein was incubated with 2,4-dinitrophenylhydrazine (DNPH) (Sigma Aldrich, St. Louis, USA) for 25 minutes, followed by addition of $0.5 \% \beta$-mercaptoethanol (Sigma Aldrich, St. Louis, USA). The reaction products were resolved by SDS-PAGE and transferred to a nitrocellulose membrane. The membrane was incubated with a rabbit anti-DNP antibody (1:300 dilution in PBS-T), and a goat anti-rabbit-HRP antibody (1:2000 dilution in PBS-T) (Santa Cruz Biotechnology, Santa Cruz, CA, USA). A molecular weight marker, containing oxidized proteins, was loaded into all gels as a positive control. Densitometric analyses were performed using the ImageJ Software (NIH, USA).

Total carbonyl content was quantified using the method described by Guedes and coworkers [15], with some modifications: 40 to $80 \mu \mathrm{g}$ of VP6 were derivatized with $160 \mu \mathrm{L}$ DNPH $(10 \mathrm{mM})$ for $1 \mathrm{~h}$ at room temperature in the dark, then samples were washed three times with TCA (20\%) and centrifuged at $12,000 \mathrm{x} \mathrm{g}$ for $20 \mathrm{~min}$. Supernatants were discarded and pellets were washed three times with $160 \mu \mathrm{L}$ of ethanol/ethyl acetate solution $(1: 1, \mathrm{v} / \mathrm{v})$ to remove DNPH excess. Finally, the pellet was dissolved in $100 \mu \mathrm{L}$ of $6 \mathrm{M}$ guanidine hydrochloride and incubated at $37^{\circ} \mathrm{C}$ for $10 \mathrm{~min}$. Absorbance was measured at $370 \mathrm{~nm}$ in a Nanodrop 1000 spectrophotometer (Thermo Fisher Scientific, USA). The carbonyl content was calculated using an absorption coefficient of $22,000 \mathrm{M}^{-1} \mathrm{~cm}^{-1}$ [36].

\section{Dityrosine formation and intrinsic fluorescence of aromatic amino acids}

Dityrosine formation was detected using fluorescence emission at 320 to $500 \mathrm{~nm}$, at an excitation wavelength of $315 \mathrm{~nm}$, with a slit width of $2.5 \mathrm{~nm}$ and a scan speed of $50 \mathrm{~nm} / \mathrm{min}$. Temperature was controlled at $27^{\circ} \mathrm{C}$. Data were acquired with the FLWinlab software (Perkin Elmer Instruments, MA; USA).

Fluorescence scans were performed with a Luminiscence spectrometer LS55 (Perkin Elmer Instruments, MA, USA) at excitation wavelengths of 280 or $295 \mathrm{~nm}$ using a slit width of $2.5 \mathrm{~nm}$. Emission spectra were recorded from 280 to $600 \mathrm{~nm}$ using a slit width of $2.5 \mathrm{~nm}$ and a scan speed of $50 \mathrm{~nm} / \mathrm{min}$. Temperature was controlled at $27^{\circ} \mathrm{C}$. Data were acquired with the FLWinlab software (Perkin Elmer Instruments, MA; USA) and the center of fluorescence spectral mass (CSM) was calculated using the following equation [45]:

$$
C S M=\frac{\sum_{280 \mathrm{~nm}}^{500 \mathrm{~nm}} v_{i} * R F U}{\sum_{280 \mathrm{~nm}}^{500 \mathrm{~nm}} \mathrm{RFU}}
$$

where $v_{i}$ represents the wavenumber $\left(\mathrm{cm}^{-1}\right)$ and RFU the relative fluorescence units.

\section{Abbreviations}

AAPH: 2,2'-azobis(2-amidinopropane) dihydrochloride; BSA: Bovine serum albumin; C: Carbonyl; CSM: Center of fluorescence spectral mass; DLS: Dynamic light scattering; HBsAg: Hepatitis B surface antigen; $K_{D}$ : Partition coefficient; MCO: Metal catalyzed oxidation; p: Protein; RFU: Relative fluorescence units; ROS: Reactive oxygen species; SEC: Size exclusion chromatography; TEM: Transmission electron microscopy; $V_{0}$ : Column void volume; $V_{t}$ : Total column volume; VP6 ${ }_{N T}$ : VP6 nanotubes; VP6 U: Unassembled VP6.

\section{Competing interests}

The authors declare that they have no competing interests.

\section{Authors' contributions}

RMCA performed the study design and the experimental work, participated in the data analysis and manuscript writing. WARL and BV participated in the study design, data analysis and manuscript writing. OTR participated in the study design, data analysis and critically revised the manuscript. LAP conceived and coordinated the study, participated in the study design, data analysis and manuscript writing. All authors read and approved the final manuscript.

\section{Acknowledgements}

Technical assistance by Vanessa Hernández, Ana Ruth Pastor, Guadalupe Zavala and Alba Lecona. TEM at the electron microscopy units of IBT-UNAM and the INSP, México. Funding by PAPIIT-UNAM IT-200113. RCA was supported by CONACYT and the Sistema Nacional de Investigadores during his graduate studies.

Received: 14 January 2014 Accepted: 10 February 2014 Published: 17 February 2014

\section{References}

1. Palomares LA, Ramírez OT: Challenges for the production of virus-like particles in insect cells: the case of rotavirus-like particles. Biochem Eng J 2009, 45:158-167.

2. Pastor AR, Rodríguez-Limas WA, Contreras MA, Esquivel E, EsquivelGuadarrama F, Ramírez OT, Palomares LA: The assembly conformation of 
rotavirus VP6 determines its protective efficacy against rotavirus challenge in mice. Vaccine. in press.

3. Plascencia Villa G, Saniger JM, Ascencio JA, Palomares LA, Ramírez OT: Use of recombinant rotavirus VP6 nanotubes as a multifunctional template for the synthesis of nanobiomaterials functionalized with metals. Biotechnol Bioeng 2009, 104:871-881.

4. Rodríguez-Limas WA, Sekar K, Tyo KE: Virus-like particles: the future of microbial factories and cell-free systems as platforms for vaccine development. Curr Opin Biotechnol 2013, 24:1089-1093.

5. Hawe A, Wiggenhorn M, van de Weert M, Garbe JH, Mahler H, Jiskoot W: Forced degradation of therapeutic proteins. J Pharm Sci 2012, 101:895-913.

6. Li S, Schöneich C, Borchardt RT: Chemical instability of protein pharmaceuticals: mechanisms of oxidation and strategies for stabilization. Biotechnol Bioeng 1995, 48:490-500.

7. Torosantucci R, Schöneich C, Jiskoot W: Oxidation of therapeutic proteins and peptides: structural and biological consequences. Pharm Res 2013:1-13. http://dx.doi.org/10.1007/s11095-013-1199-9.

8. Meucci E, Mordente A, Martorana G: Metal-catalyzed oxidation of human serum albumin: conformational and functional changes. Implications in protein aging. J Biol Chem 1991, 266:4692-4699.

9. Dean R, Fu S, Stocker R, Davies M: Biochemistry and pathology of radical-mediated protein oxidation. Biochem J 1997, 324:1-18.

10. Barelli S, Canellini G, Thadikkaran L, Crettaz D, Quadroni M, Rossier JS, Tissot JD, Lion N: Oxidation of proteins: basic principles and perspectives for blood proteomics. Proteom Clin Appl 2008, 2:142-157.

11. Goetz ME, Luch A: Reactive species: a cell damaging rout assisting to chemical carcinogens. Cancer Lett 2008, 266:73-83.

12. Baron $C P$, Refsgaard HH, Skibsted LH, Andersen ML: Oxidation of bovine serum albumin initiated by the Fenton reaction-effect of EDTA, tertbutylhydroperoxide and tetrahydrofuran. Free Radic Res 2006, 40:409-417.

13. Liu D, Ren D, Huang H, Dankberg J, Rosenfeld R, Cocco MJ, Li L, Brems DN, Remmele RL Jr: Structure and stability changes of human IgG1 Fc as a consequence of methionine oxidation. Biochemistry 2008, 47:5088-5100.

14. Hu D, Qin Z, Xue B, Fink AL, Uversky VN: Effect of methionine oxidation on the structural properties, conformational stability, and aggregation of immunoglobulin light chain LEN. Biochemistry 2008, 47:8665-8677.

15. Guedes S, Vitorino R, Domingues R, Amado F, Domingues P: Oxidation of bovine serum albumin: identification of oxidation products and structural modifications. Rapid Commun Mass Sp 2009, 23:2307-2315.

16. Mulinacci F, Capelle MAH, Gurny R, Drake AF, Arvinte T: Stability of human growth hormone: influence of methionine oxidation on thermal folding J Pharm Sci 2011, 100:451-463.

17. Davies K, Delsignore M, Lin S: Protein damage and degradation by oxygen radicals. II. Modification of amino acids. J Biol Chem 1987, 262:9902-9907.

18. Hawkins $C L$, Davies MJ: Generation and propagation of radical reactions on proteins. BBA-Bioenerg 2001, 1504:196-219.

19. Sano D, Pintó RM, Omura T, Bosch A: Detection of oxidative damages on viral capsid protein for evaluating structural integrity and infectivity of human norovirus. Environ Sci Technol 2009, 44:808-812.

20. Meunier S, Strable E, Finn M: Crosslinking of and coupling to viral capsid proteins by tyrosine oxidation. Chem Biol 2004, 11:319-326.

21. Rule Wigginton K, Menin L, Montoya JP, Kohn T: Oxidation of virus proteins during $\mathrm{UV}_{254}$ and singlet oxygen mediated inactivation. Environ Sci Technol 2010, 44:5437-5443.

22. Bounty S, Rodriguez R, Linden KG: Inactivation of Adenovirus Using Low-Dose UV/ $\mathrm{H}_{2} \mathrm{O}_{2}$ Advanced Oxidation. Water Res 2012, 46:6273-6278.

23. Ogata $\mathrm{N}$ : Inactivation of influenza virus haemagglutinin by chlorine dioxide: oxidation of the conserved tryptophan 153 residue in the receptor-binding site. J Gen Virol 2012, 93:2558-2563.

24. Tleugabulova D, Falcón V, Pentón E, Sewer M, Fleitas Y: Aggregation of recombinant hepatitis $B$ surface antigen induced in vitro by oxidative stress. J Chromatogr B 1999, 736:153-166.

25. Lepault J, Petitpas I, Erk I, Navaza J, Bigot D, Dona M, Vachette P, Cohen J, Rey FA: Structural polymorphism of the major capsid protein of rotavirus. EMBO J 2001, 20:1498-1507.

26. Mathieu M, Petitpas I, Navaza J, Lepault J, Kohli E, Pothier P, Prasad BV Cohen J, Rey FA: Atomic structure of the major capsid protein of rotavirus: implications for the architecture of the virion. EMBO J 2001, 20:1485-1497.
27. Blazevic V, Lappalainen S, Nurminen K, Huhti L, Vesikari T: Norovirus VLPS and rotavirus VP6 protein as combined vaccine for childhood gastroenteritis. Vaccine 2011, 29:8126-8133.

28. Carreño-Fuentes L, Ascencio JA, Medina A, Aguila S, Palomares LA, Ramírez OT: Strategies for specifically directing metal functionalization of protein nanotubes: constructing protein coated silver nanowires. Nanotechnology 2013, 24:235602.

29. Plascencia-Villa G, Mena JA, Castro-Acosta RM, Fabián JC, Ramírez OT, Palomares LA: Strategies for the purification and characterization of protein scaffolds for the production of hybrid nanobiomaterials. J Chromatogr B 2011, 879:1105-1111.

30. Giulivi C, Davies KJ: Dityrosine: a marker for oxidatively modified proteins and selective proteolysis. Methods Enzymol 1994, 233:363-371.

31. Mahler HC, Friess W, Grauschopf U, Kiese S: Protein aggregation: pathways, induction factors and analysis. J Pharm Sci 2009, 98:2909-2934.

32. Auer S, Dobson CM, Vendruscolo M: Characterization of the nucleation barriers for protein aggregation and amyloid formation. HFSP J 2007, 1:137-146.

33. Mena JA, Ramírez OT, Palomares LA: Quantification of rotavirus-like particles by gel permeation chromatography. J Chromatogr B 2005, 824:267-276.

34. Stadtman $E$, Levine R: Free radical-mediated oxidation of free amino acids and amino acid residues in proteins. Amino Acids 2003, 25:207-218.

35. Garrison WM: Reaction mechanisms in the radiolysis of peptides, polypeptides, and proteins. Chem Rev 1987, 87:381-398.

36. Headlam HA, Davies MJ: Markers of protein oxidation: different oxidants give rise to variable yields of bound and released carbonyl products. Free Radic Bio Med 2004, 36:1175-1184.

37. Fedorova M, Bollineni RC, Hoffmann R: Protein carbonylation as a major hallmark of oxidative damage: update of analytical strategies. Mass Spectrom Rev 2014, 33:79-97.

38. Dalle-Donne I, Rossi R, Giustarini D, Milzani A, Colombo R: Protein carbonyl groups as biomarkers of oxidative stress. Clin Chim Acta 2003, 329:23-38.

39. Rao R, Møller IM: Pattern of occurrence and occupancy of carbonylation sites in proteins. Proteomics 2011, 11:4166-4173.

40. Jeong J, Jung Y, Na S, Jeong J, Lee E, Kim M-S, Choi S, Shin D-H, Paek E, Lee $\mathrm{H}-\mathrm{Y}$ : Novel oxidative modifications in redox-active cysteine residues. Mol Cell Proteomics 2011, 10:M110.000513.

41. Shigenaga MK, Hagen TM, Ames BN: Oxidative damage and mitochondrial decay in aging. Proc Natl Acad Sci U S A 1994, 91:10771-10778.

42. Singh SK: Impact of product-related factors on immunogenicity of biotherapeutics. J Pharm Sci 2011, 100:354-387.

43. Rodríguez M, Wood C, Sanchez-López R, Castro-Acosta RM, Ramírez OT, Palomares LA: Understanding internalization of rotavirus VP6 nanotubes by cells: towards a recombinant vaccine. Arch Virol. In press.

44. Simat T, Steinhart H: Oxidation of free tryptophan and tryptophan residues in peptides and proteins. J Agr Food Chem 1998, 46:490-498.

45. Mohana-Borges R, Silva JL, de Prat-Gay G: Protein folding in the absence of chemical denaturants. Reversible pressure denaturation of the noncovalent complex formed by the association of two protein fragments. J Biol Chem 1999, 274:7732-7740.

46. Vivian JT, Callis PR: Mechanisms of tryptophan fluorescence shifts in proteins. Biophys J 2001, 80:2093-2109.

47. Lakowicz JR: Principles of fluorescence spectroscopy. Springer; 2009.

48. Erk I, Huet J-C, Duarte M, Duquerroy S, Rey F, Cohen J, Lepault J: A zinc ion controls assembly and stability of the major capsid protein of rotavirus. J Virol 2003, 77:3595-3601.

doi:10.1186/1475-2859-13-25

Cite this article as: Castro-Acosta et al:: Effect of metal catalyzed oxidation in recombinant viral protein assemblies. Microbial Cell Factories 2014 13:25. 